\title{
RASIO KEUANGAN : DETERMINAN PERTUMBUHAN LABA STUDI EMPIRIS PADA PERUSAHAAN MANUFAKTUR SEKTOR INDUSTRI DASAR DAN KIMIA YANG TERDAFTAR DI BURSA EFEK INDONESIA
}

\author{
Susi Susilawati ${ }^{1}$ \\ ${ }^{1}$ STIE Muhammadiyah Jakarta, sslawati10@gmail.com
}

\begin{abstract}
ABSTRAK
Penelitian ini bertujuan untuk memperkuat pengaruh Rasio Keuangan terhadap Pertumbuhan Pendapatan (BEI). Pemilihan sampel dengan purposive sampling adalah 61 perusahaan yang mengadakan tahun 2012 - 2016 yaitu 5 tahun dan hanya 21 sampel yang diambil dengan jumlah pengamatan 105, pemilihan berdasarkan laporan audit tahunan. Variabel independen yang diteliti adalah rasio keuangan yang terdiri dari Current Ratio (CR), Debt to Asset Ratio (DAR), Total Asset Turnover (TAT) dan Net Profit Margin (NPM), sedangkan variabel dependennya adalah Earning Growth (EG). Hasil dari penelitian ini menunjukkan secara simultan rasio lancar, rasio hutang terhadap hutang, total perputaran aktiva dan margin laba bersih yang signifikan terhadap pertumbuhan pendapatan pada perusahaan manufaktur di Bursa Efek Indonesia. Secara parsial, hanya variabel aset lancar tidak berpengaruh signifikan terhadap pertumbuhan pendapatan. Rasio rasio utang terhadap aset, total perputaran aset dan margin laba bersih memiliki pengaruh yang signifikan terhadap pertumbuhan laba di Bursa Efek Indonesia.
\end{abstract}

Kata Kunci: rasio lancar, rasio utang terhadap aset, total perputaran aset, margin laba bersih

\begin{abstract}
This study aims to strengthen the influence of Financial Ratios to Earning Growth (BEI). The sample selection with purposive sampling were 61 companies which held the year 2012 - 2016 ie 5 years and only 21 samples taken with the number of observation 105, the selection based on annual audit report. The independent variables studied are financial ratios consisting of Current Ratio (CR),Debt to Asset Ratio (DAR), Total Asset Turnover (TAT) and Net Profit Margin (NPM), while the dependent variable is Earning Growth (EG). The results of this study show simultaneously current ratio, debt to ssset ratio, total asset turnover and net profit margin significant to earning growth at manufacturing companies in Indonesia Stock Exchange. Partially, only the current asset variable has not significant effect to earning growth. Ratio of debt to Assets ratio, total asset turnover and net profit margin have a significant influence to earning growth in Indonesia Stock Exchange.
\end{abstract}

Keywords: current ratio, debt to asset ratio, total asset turnover, net profit margin 


\section{PENDAHULUAN}

Dalam mengukur dan menganalisa baik tidaknya kondisi suatu perusahaan alat utama yang dipakai adalah laporan keuangan. Laporan Keuangan merupakan informasi keuangan suatu perusahaan dalam jangka waktu satu periode tertentu, umumnya menyajikan laporan neraca, laporan laba rugi, laporan perubahan modal, laporan arus kas serta catatan atas laporan keuangan. Melalui laporan keuangan tersebut semua pihak yang berkepentingan baik pihak internal maupun pihak eksternal dapat mengetahui secara pasti kinerja keuangan perusahaan. Pihak yang berkepentingan tersebut sesuai dengan yang ada pada Pernyataan Standar Akuntansi Keuangan (PSAK) nomor 1 (09) dimana dinyatakan bahwa pemakai laporan keuangan meliputi investor sekarang dan investor potensial, karyawan, pemberi pinjaman, pemasok dan kredit usaha lainnya, pelanggan, pemerintah serta lembaga-lembaganya, dan masyarakat. Laporan keuangan memberikan gambaran mengenai kinerja suatu perusahaan atau kondisi keuangan perusahaan yang telah dicapai dalam periode tertentu. Laporan keuangan juga membantu bagi manajer untuk mengambil suatu keputusan dimasa yang akan datang.

Menurut Jogiyanto HM (2003:59) menyatakan bahwa informasi yang diperlukan oleh para investor di pasar modal tidak hanya informasi yang bersifat fundamental saja, tetapi juga informasi yang bersifat teknikal. Informasi yang bersifat fundamental diperoleh dari kondisi intern perusahaan, dan informasi yang bersifat teknikal diperolah dari luar perusahaan, seperti ekonomi, politik, finansial dan faktor lainnya. Informasi yang diperoleh dari kondisi intern perusahaan yang lazim digunakan adalah informasi laporan keuangan, salah satunya adalah analisis rasio keuangan. James C van Horne yang dikutip dari Kasmir (2016:104) menyatakan bahwa rasio keuangan merupakan indeks yang menghubungkan 2 (dua) angka akuntansi dan diperoleh dengan membagi satu angka dengan angka lainnya. Rasio keuangan perusahaan diklasifikasikan menjadi lima kelompok, yaitu : (1) Rasio Likuiditas (liquidity ratios) yaitu jenis rasio yang menunjukkan kemampuan perusahaan untuk memenuhi kewajiban jangka pendek, (2) Rasio Solvabilitas (leverage atau solvency ratios) yaitu jenis rasio yang menunjukkan kemampuan perusahaan untuk memenuhi seluruh kewajibannya baik jangka pendek ataupun jangka panjang, (3) Rasio Aktivitas (activity ratios) yaitu jenis rasio yang menunjukkan tingkat efektifitas penggunaan aktiva atau kekayaan perusahaan, (4) Rasio Profitabilitas dan Rentabilitas (profitability ratios) yaitu jenis rasio yang menunjukkan tingkat imbalan atau perolehan (keuntungan) dibanding penjualan atau aktiva, (5) Rasio Investasi (investment ratios) yaitu jenis rasio yang menunjukkan rasio investasi dalam surat berharga atau efek, khususnya saham dan obligasi (Rahardjo, 2007 : 104).

FASB Statement of Financial Accounting Concepts No 1 (Hendriksen, 1996) menyatakan bahwa sasaran utama pelaporan keuangan adalah informasi tentang prestasi perusahaan yang disajikan melalui pengukuran laba dan komponennya. Meskipun demikian, tidak berarti bahwa laba yang besar diartikan telah menggambarkan kondisi perusahaan yang efektif karena ada faktor lain yang dapat dijadikan sebagai parameter keberhasilan perusahaan, yaitu berdasarkan kinerja manajemen dalam menghasilkan laba dimasa mendatang.

Menurut Wetson dan Copeland (1995), salah satu alat ukur keberhasilan kinerja manajemen dalam mengelola perusahaan secara efektif dan efisien adalah analisis rasio pertumbuhan. Rasio pertumbuhan salah satunya dengan melihat pertumbuhan laba dimana pertumbuhan laba dapat mencerminkan tingkat keberhasilan manajemen. Pertumbuhan laba juga merupakan selisih laba bersih tahun tertentu dengan laba bersih tahun sebelumnya dibagi dengan laba bersih tahun sebelumnya. (Harahap, 2011). Menurut Ikatan Akuntan Indonesia (2007)"penghasilan bersih (laba) seringkali digunakan sebagai ukuran kinerja atau sebagai dasar bagi ukuran yang lain seperti imbalan investasi (return on investmen) atau penghasilan per saham (earnig per share)". Oleh karena itu pertumbuhan laba menjadi salah satu alat evaluasi perusahaan.

Khalidazia Ibnu Khaldun (2014) dan Ade Gunawan (2013) dalam penelitiannya menunjukkan bahwa tidak terdapat pengaruh signifikan current ratio terhadap pertumbuhan laba, sedangkan menurut Windi Hartini (2012) menyatakan bahwa current ratio berpengaruh terhadap pertumbuhan laba. 
Ima Andriyani (2015) dalam penelitiannya menyatakan bahwa debt to asset ratio tidak memiliki pengaruh signifikan terhadap pertumbuhan laba sedangkan menurut Windi Hartini (2012) menyatakan bahwa debt to asset ratio berpengaruh terhadap pertumbuhan laba

Purwanto (2016) hasil penelitiannya menunjukkan bahwa total asset turnover memiliki pengaruh signifikan terhadap pertumbuhan laba sedangkan menurut Ima Andriyani (2015) menyatakan bahwa total asset turnover tidak berpengaruh signifikan terhadap pertumbuhan laba.

Novian P. Hamidu (2013) dan I Nyoman Kusuma Adnyana (2012) dalam penelitiannya menyatakan bahwa net profit margin memiliki pengaruh signifikan terhadap pertumbuhan laba sedangkan menurut Meyti (2005) menyatakan bahwa net profit margin tidak berpengaruh signifikan terhadap pertumbuhan laba.

Berdasarkan latar belakang dan riset gap yang terjadi di atas peneliti meneliti kembali mengenai pengaruh rasio keuangan terhadap pertumbuhan laba dengan membatasi rasio keuangan hanya menghitung current ratio, debt to asset ratio, total assets turnover, net profit margin. Maka rumusan masalahnya adalah sebagai berikut:

1. Bagaimana pengaruh current ratio terhadap pertumbuhan laba pada perusahaan manufaktur sektor industri dasar dan kimia yang terdaftar di Bursa Efek Indonesia ?

2. Bagaimana pengaruh debt to asset ratio terhadap pertumbuhan laba pada perusahaan manufaktur sektor industri dasar dan kimia yang terdaftar di Bursa Efek Indonesia ?

3. Bagaimana pengaruh total asset turnover terhadap pertumbuhan laba pada perusahaan manufaktur sektor industri dasar dan kimia yang terdaftar di Bursa Efek Indonesia ?

4. Bagaimana pengaruh net profit margin terhadap pertumbuhan laba pada perusahaan manufaktur sektor industri dasar dan kimia terdaftar di Bursa Efek Indonesia?

5. Bagaimana pengaruh current assets ratio, debt to asset ratio, total asset turnover dan net profit margin secara bersama-sama (simultan) terhadap pertumbuhan laba

Berdasarkan rumusan masalah di atas maka tujuan dari penelitian ini adalah:

1. Menganalisis pengaruh current ratio terhadap pertumbuhan laba pada perusahaan manufaktur sektor industri dasar dan kimia yang terdaftar di Bursa Efek Indonesia

2. Menganalisis pengaruh debt to assets ratio terhadap pertumbuhan laba pada perusahaan manufaktur sektor industri dasar dan kimia yang terdaftar di Bursa Efek Indonesia

3. Menganalisis pengaruh total asset turnover terhadap pertumbuhan laba pada perusahaan manufaktur sektor industri dasar dan kimia yang terdaftar di Bursa Efek Indonesia

4. Menganalisis pengaruh net profit margin terhadap pertumbuhan laba pada perusahaan manufaktur sektor industri dasar dan kimia yang terdaftar di Bursa Efek Indonesia

5. Menganalisa pengaruh current assets ratio, debt to assets ratio, total asset turnover dan net profit margin secara bersama-sama (simultan) terhadap pertumbuhan

\section{KAJIAN LITERATUR \\ Landasan Teori \\ Pertumbuhan Laba}

Agar dapat melangsungkan hidupnya yang terus menerus, suatu perusahaan harus mampu menghasilkan laba setiap periodenya dimana pengertian laba menurut Soemarso (2010) adalah selisih lebih pendapatan atas beban sehubungan dengan kegiatan usaha. Kemampuan dalam mempertahankan laba dapat dilihat dari pertumbuhan laba dari satu periode ke periode berikutnya, dengan melihat apakah perusahaan mengalami peningkatan atau penurunan laba. Menurut Stice, Stice, Skousen (2009:240) laba adalah pengambilan atas investasi kepada pemilik. Hal ini mengukur nilai yang dapat diberikan oleh entitas kepada investor dan entitas masih memiliki kekayaan yang sama dengan posisi awalnya. Sedangkan Menurut Suwardjono (2008: 464) laba diartikan sebagai imbalan atas upaya perusahaan menghasilkan barang dan jasa. Ini berarti laba merupakan kelebihan pendapatan diatas biaya (biaya total yang melekat dalam kegiatan produksi dan penyerahan barang / jasa). Tugas utama manajer adalah memastikan dan mempertahankan kelangsungan hidup perusahaan yaitu salah satunya dalam mempertahankan kemampuan 
menghasilkan laba setiap periodenya karena laba merupakan bagian dari salah satu alat ukur bagi para pemegang saham dalam mengevaluasi kinerja manajer dan perusahaan.

Pemegang saham mengharapkan laba yang terus meningkat artinya kinerja perusahaan mengalami peningkatan karena dengan adanya peningkatan laba akan meningkatkan juga pengembalian kepada pemegang saham. Oleh karena itu perlunya pengetahuan mengenai pertumbuhan laba karena dengan mengetahui pertumbuhan laba yang diperoleh perusahaan maka manajemen dapat menentukan apakah terdapat peningkatan atau penurunan kinerja keuangan suatu perusahaan dan menentukan tindakan apa yang harus dilakukan agar laba terus meningkat atau mempertahankannya. Pertumbuhan laba juga dipengaruhi oleh perubahan komponenkomponen lain dalam laporan keuangan seperti penjualan, beban-beban, pajak, pos luar biasa, selain itu juga faktor eksternal dapat mempengaruhi laba seperti inflasi yang menyebabkan adanya peningkatan harga jual. Pertumbuhan laba dihitung dengan cara mengurangkan laba periode sekarang dengan laba periode sebelumnya kemudian dibagi dengan laba pada periode sebelumnya (Harahap, 2015, 310).

Pertumbuhan Laba $=$

$\frac{\mathrm{Y}_{\mathrm{t}}-\mathrm{Y}_{\mathrm{t}-1} \quad \mathrm{x}}{\mathrm{Y}_{\mathrm{t}-1}} 100 \%$

Keterangan:

Yt $=$ laba bersih tahun berjalan

Yt-1 = laba bersih tahun sebelumnya

Karakteristik laba (Belkaoui, 2007 : 217) :

1) Laba didasarkan pada transaksi aktual terutama yang berasal dari penjualan barang dan jasa.

2) Laba didasarkan pada postulat periodisasi, artinya prestasi perusahaan pada periode tertentu.

3) Laba didasarkan pada prinsip pendapatan yang membutuhkan pemahaman khusus tentang definisi, pengukuran dan pengakuan pendapatan.

4) Laba membutuhkan pengukuran tentang biaya dalam bentuk biaya historis yang dikeluarkan perusahaan untuk mendapatkan pendapat tertentu.

5) Laba didasarkan pada prinsip perbandingan antara pendapatan dan biaya yang relevan dan kaitan dengan pendapatan tersebut

Menurut M. Nafarin (2007: 231), peranan laba bagi perusahaan yaitu:

1) Suatu kekuatan pokok agar perusahaan dapat tetap bertahan untuk jangka pendek dan jangka panjang perusahaan.

2) Balas jasa atas dana yang ditanam perusahaan.

3) Salah satu sumber dana perusahaan.

4) Sumber dana jaminan surat karyawan Daya tarik bagi pihak ketiga yang ingin menanam dana. Nafarin, M, (2007)

\section{Jenis - Jenis Laba}

Laba adalah salah satu hal yang paling penting dalam sebuah perusahaan, laba terdiri dari atas beberapa jenis yaitu :

1) Laba kotor, yaitu selisih antara hasil penjualan dengan harga pokok penjualan.

2) Laba opersional, merupakan hasil dari aktivitas-aktivitas yang termasuk rencana perusahaan kecuali ada perubahan-perubahan besar dalam perekonomiannya.

3) Laba sebelum dikurangi pajak atau EBIT (Earning Before Tax), adalah laba operasional ditambah hasil dan biaya di luar operasi biasa perusahaan. 
4) Laba setelah pajak atau laba bersih, yaitu laba yang telah dikurangi seluruh pajak yang ada

Adapun menurut Kasmir (2016:303), jenis laba terbagi menjadi:

- Laba Kotor (gross Profit) adalah laba yang didapatkan sebelum dikurangi biaya yang menjadi beban perusahaan. Atau dengan kata lain, laba kotor adalah laba keseluruhan yang perusahaan peroleh.

- Laba Bersih (Net Profit) adalah laba yang sudah dikurangi biaya yang merupakan beban perusahaan dalam suatu periode tertentu termasuk pajak

\section{Laporan Keuangan}

Ikatan Akuntan Indonesia (2009:1) menyebutkan bahwa laporan keuangan merupakan bagian dari proses pelaporan keuangan. Laporan keuangan yang lengkap biasanya meliputi neraca, laporan laba rugi, laporan perubahan posisi keuangan (yang dapat disajikan dalam berbagai cara seperti, misalnya sebagai laporan arus kas atau laporan arus dana), catatan dan laporan lain, serta materi penjelasan yang merupakan bagian integral dari laporan keuangan. Laporan keuangan (Riyanto, 2011) memberikan ikhtisar mengenai keadaan finansial suatu perusahaan, dimana neraca (balance sheet) mencerminkan nilai aktiva, hutang, dan modal sendiri pada suatu saat tertentu, dan laporan rugi dan laba(income statement) mencerminkan hasil-hasil yang dicapai selama suatu periode tertentu biasanya meliputi periode tahun. Dari hasil laporan keuangan tersebut kemudian di analisis dan diinterpretasikan agar laporan keuangan lebih berguna dan dapat dipahami oleh semua pemakai laporan keuangan antara lai.n investor, karyawan, kreditur, pelanggan, pemerintah, masyarakat dan manajemen perusahaan itu sendiri. Salah satu analisis keuangan adalah dengan analisis rasio keuangan. Menurut Sulfida (2010), analisis laporan keuangan meliputi perhitungan dan interpretasi rasio keuangan. Rasio keuangan dapat dihitung dari isi informasi keuangan dalam laporan keuangan sehingga menunjukkan kekuatan perusahaan. Menurut Kasmir (2016: 104) Rasio keuangan merupakan kegiatan membandingkan angka-angka yang ada dalam laporan keuangan dengan cara membagi satu angka dengan angka lainya.

Weston dalam Kasmir (2016: 106) menyebutkan bentuk-bentuk rasio keuangan yang meliputi rasio likuiditas (current ratio dan quick ratio), rasio solvabilitas (debt ratio, time interest earned, fixed charge coverage dan cash flow coverage), rasio activity (inventory turnover, average collection period, fixed assets turn over dan total assets turn over), profitabilitas (profit margin on sales, basic earning power, return on total assets dan return on total equity), rasio pertumbuhan (pertumbuhan penjualan, laba bersih, perndapatan per saham dan deviden per saham) serta rasio penilaian (rasio harga saham terhadap pendapatan dan rasio nilai pasar saham terhadap nilai buku).

1) Rasio Likuiditas

Menurut Sutrisno (2009: 114), rasio likuiditas adalah kemampuan perusahaan untuk membayar kewajiban-kewajibannya yang segera harus dipenuhi. Jenis-jenis rasio likuiditas yang dapat digunakan perusahaan untuk mengukur kemampuan yaitu (Kasmir, 2016) :

a. Rasio Lancar (Current Ratio)

Rasio lancar merupakan rasio yang mengukur kemampuan perusahaan dalam membayar kewajiban jangka pendek atau hutang yang segera jatuh tempo pada saat ditagih secara keseluruhan (Kasmir, 2016: 134). . Standar rata-rata industri untuk curent ratio ini adalah $150 \%$ (1,5 kali). Rasio ini dapat diukur dengan rumus:

Current Ratio $=$

Aktiva Lancar x 100\%

Hutang Lancar 


\section{b. Rasio Cepat (Quick Ratio)}

Rasio ini menunjukkan kemampuan perusahaan untuk membayar utang dengan aset yang likuid. Rasio ini menunjukkan besarnya alat likuid yang paling cepat yang biasa digunakan untuk melunasi hutang lancar. Standar rata-rata industri untuk quick ratio ini adalah 150\% (1,5 kali) (Kasmir, 2016 : 138). Rasio ini dapat diukur dengan rumus:

$\mathrm{QR}=\underline{\mathrm{AL}-\text { Persediaan }} \times 100 \%$

Hutang Lancar

\section{c. Rasio Kas (Cash Ratio)}

Rasio kas merupakan rasio yang digunakanuntuk mengukur seberapa besar uang kas yang tersedia untuk membayar utang (Kasmir, 2016: 138).

Cash Ratio $=\underline{\text { Kas atau Setara Kas }}$

Utang Lancar

d. Rasio Perputaran Kas

Rasio perputaran kas digunakan untuk mengukur tingkat ketersediaan kas untuk membayar tagihan (utang) dan biaya-biaya yang berkaitan dengan penjualan (Kasmir, 2016: 140). Rasio ini dapat diukur dengan rumus:

RPK $=$ Penjualan Bersih

Modal Kerja Bersih

e. Inventory to Net Working Capital

Inventory to Net Working Capital merupakan rasio yang digunakan untuk mengukur atau membandingkan antara jumlah persediaan yang ada dengan modal kerja perusahaan (Kasmir, 2016: 141). Rasio ini dapat diukur dengan rumus: Inventory to $N W C=$ inventory current ratio - current liabilities

Dari Seluruh analisis rasio likuiditas di atas yang berhubungan dengan penelitian ini adalah rasio lancar (Current Ratio).

2) Rasio Solvabilitas (Leverage Ratio)

Menurut Sutrisno (2009: 15), rasio solvabilitas adalah rasio untuk mengukur kemampuan perusahaan untuk memenuhi semua kewajibannya apabila perusahaan dilikuidasi. Jenis-jenis rasio solvabilitas adalah :

a. Debt to Assets Ratio (DAR)

Rasio ini mengukur berapa besar aktiva yang dibiayai oleh kreditur. Semakin tinggi debt ratio semakin besar jumlah modal pinjaman yang digunakan di dalam menghasilkan keuntungan bagi perusahaan (Syamsudin, 2009: 54). Rasio ini dapat diukur dengan rumus:

Debt to assets ratio $=$ Total Hutang x $100 \%$

Total Aktiva

b. Debt to Equity Ratio (DER)

Harahap (2010 : 303) menyatakan bahwa rasio DER menggambarkan sampai sejauh mana modal pemilik dapat menutupi utang-utang kepada pihak luar. Semakin kecil rasio ini semakin baik. Dengan kata lain, rasio ini berfungsi untuk mengetahui setiap rupiah modal sendiri yang dijadikan untuk jaminan utang. Rasio ini dapat diukur dengan rumus:

Debt to Equity Ratio =

Total Hutang

Modal 
c. Long Term Debt to Equity Ratio

Menurut Kasmir (2016 : 159) merupakan rasio antara utang jangka panjang dengan modal sendiri . Rasio ini dapat diukur dengan rumus :

Long term debt to equity ratio $=$

Utang Jangka Panjang

Modal Pemilik

d. Times Interest Earned

Menurut Kasmir $(2016$; 160) merupakan rasio untuk mencari jumlah kali perolehan bunga. Rasio ini dapat diukur dengan rumus :

Time interest earned $=$

Laba Sebelum Bunga dan Pajak

Bunga Utang

e. Fixed Charge Coverage Menurut Kasmir (2016 : 162) merupakan rasio yang dilakukan apabila perusahaan memperoleh utang jangka panjang atau menyewa aktiva berdasarkan kontrak sewa (lease contract). Rasio ini dapat diukur dengan rumus :

Fixed Charge Coverage $=$

Ebit+ Fixed Charges(before tax)

Fixed charge (before tax)+ interest

Dari seluruh analisis rasio di atas yang digunakan dalam penelitian ini adalah Debt to Asset Ratio (DAR).

3) Rasio Aktivitas

Rasio aktvitas adalah rasio yang menggambarkan sejauh mana suatu perusahaan mempergunakan sumber daya manusia yang dimilikinya guna menunjukkan aktivitas perusahaan (Fahmi, 2013). Jenis-jenis rasio aktivitas adalah:

a. Total Asset Turnover

Menurut Sutrisno (2012 : 209) Merupakan ukuran efektifitas pemanfaatan aktiva dalam menghasilkan penjualan. Rasio ini membandingkan antara penjualan bersih dan seluruh aktiva yang digunakan dalam suatu periode. Rasio ini dapat diukur dengan rumus :

Total Asset Turnover $=$

Penjualan Bersih

Total Aktiva

b. Perputaran Piutang (Receivables Turnover)

Kasmir (2016: 176), Rasio ini digunakan untuk mengukur berapa lama penagihan piutang selama satu periode atau berapa kali dana yang ditanam dalam piutang ini berputar dalam satu periode. Rasio ini dapat diukur dengan rumus:

Perputaran Piutang $=\underline{\text { Penjualan Bersih }}$

Piutang Bersih

c. Average Collection Periode

Average collection periode/rata-rata periode pengumpulan piutang digunakan untuk menghitung waktu atau hari rata-rata dana tertanam dalam piutang. Rasio ini dapat diukur dengan rumus:

Average Collection Periode $=360$ hari

Perputaran Piutang Dagang

d. Perputaran Persediaan (Inventory Turn Over)

Rasio ini untuk menunjukkan berapa kali jumlah barang sediaan diganti dalam satu tahun (Kasmir, 2016: 180). Rasio ini dapat diukur dengan rumus:

Perputaran Persediaan Barang Dagangan $=$

Penjualan 
e. Average Day's Inventory

Persediaan

Ialah hari rata-rata persediaan atau hari rata-rata disimpan, menunjukkan hari ratarata dana tertanam dalam persediaan. Rasio ini dapat diukur dengan rumus:

Average Day's Inventory $=\frac{\text { Persediaan Rata-rata x } 365 \text { hari }}{\text { Harga Pokok Barang Dijual }}$

f. Working Capital Turnover

Perputaran modal kerja neto ialah rasio yang membandingkan antara penjualan bersih dan modal kerja (neto) atau rata-rata modal kerja (Kasmir, 2016 : 182). Rasio ini dapat diukur dengan rumus:

Working Capital Turnover $=\quad$ Penjualan Bersih

g. Fixed Assets Turnover

Rata-rata Modal Kerja Bersih

Digunakan untuk mengukur apakah perusahaan sudah menggunakan kapasitas aktiva tetap sepenuhnya atau belum (Kasmir, 2016: 184). Rasio ini dapat diukur dengan rumus:

Fixed Assets Turnover $=$

Aktiva Tetap Bersih

Dari seluruh analisis rasio di atas, yang digunakan dalam penelitian ini adalah total assets turnover (TAT).

4) Rasio Profitabilitas

Rasio profitabilitas merupakan rasio untuk menilai kemampuan perusahaan dalam mencari keuntungan (Kasmir, 2016: 196). Analisis rasio profitabilitas ini dapat ditentukan dengan cara sebagai berikut.

a. Return On Assets (ROA)

Rasio ini digunakan untuk mengukur kemampuan manajemen perusahaan dalam memperoleh keuntungan (laba) secara keseluruhan (Van Horne \& Wachowicz, 2012). Rasio ini dapat diukur dengan rumus:

Return on Asset $=\frac{\text { EAT } \times 100 \%}{\text { Asset }}$

b. Return on Equity (ROE)

Rasio ini menunjukkan efisiensi modal sendiri, semakin besar rasio ini maka semakin baik yang artinya posisi perusahaan semakin kuat ataupun sebaliknya (Kasmir, 2016: 201). Rasio ini dapat diukur dengan rumus:

Return on Equity =

$$
\frac{\text { EAT } \times 100 \%}{\text { Equity }}
$$

c. Net Provit Margin (NPM)

Net Profit Margin adalah rasio untuk menunjukkan berapa pesentase pendapatan bersih diperoleh disetiap penjualan (Harahap, 2011 : 304). Semakin tinggi net profit margin, semakin baik operasi suatu perusahaan (Syamsuddin, 2009: 62). Rasio ini dapat diukur dengan rumus:

Net Profit Margin =

$\frac{\text { Earning After Interesst and Tax }}{\text { Sales }}$ 
Dari rasio profitabilitas di atas yang menjadi fokus dalam penelitian ini adalah Net Profit Margin (NPM) atau ratio margin laba terhadap penjualan.

\section{Kerangka Pemikiran}

Berdasarkan kerangka teori di atas, penulis dapat membuat kerangka konsep mengenai pengaruh rasio keuangan (current ratio, debt to asset ratio, total asset turnover dan net profit margin) terhadap pertumbuhan laba. Survey pada perusahaan manufaktur sektor industri dasar dan kimia yang terdaftar di Bursa Efek Indonesia, dimana (current ratio, debt to asset ratio, total asset turnover dan net profit margin) sebagai variabel bebas (independent) dan pertumbuhan laba sebagai variabel terikat (dependent).

Paradigma Penelitian (Rasio Keuangan: Determinan Pertumbuhan Laba Studi Empiris Pada Perusahaan Manufaktur Sektor Industri Dasar Dan Kimia Yang Terdaftar Di (BEI)

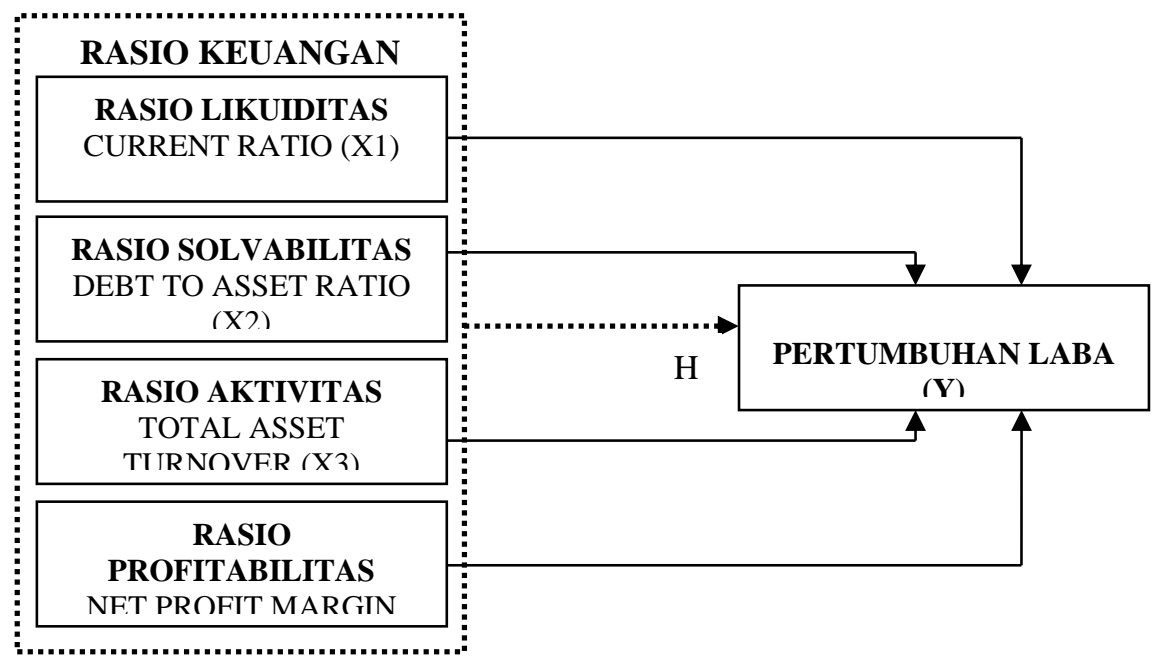

Gambar 1: Model Kerangka Penelitian

\section{Hipotesis}

Hipotesis dalam penelitian ini adalah:

a. Terdapat pengaruh signifikan current ratio terhadap pertumbuhan laba pada perusahaan manufaktur sektor industri dasar dan kimia yang terdaftar di Bursa Efek Indonesia (H1).

b. Terdapat pengaruh signifikan debt to assets ratio terhadap pertumbuhan laba pada perusahaan manufaktur sektor industri dasar dan kimia yang terdaftar di Bursa Efek Indonesia (H2).

c. Terdapat pengaruh signifikan total asset turnover terhadap pertumbuhan laba pada perusahaan manufaktur sektor industri dasar dan kimia yang terdaftar di Bursa Efek Indonesia (H3).

d. Terdapat pengaruh signifikan net profit margin terhadap pertumbuhan laba pada perusahaan manufaktur sektor industri dasar dan kimia yang terdaftar di Bursa Efek Indonesia (H4).

e. Terdapat pengaruh signifikan current assets ratio, debt to assets ratio, total asset turnover dan net profit margin secara bersama-sama (simultan) terhadap pertumbuhan laba pada perusahaan manufaktur sektor industri dasar dan kimia yang terdaftar di Bursa Efek Indonesia (H5). 


\section{METODE PENELITIAN}

Penelitian yang dilakukan adalah penelitian kuantitatif dimana jenis data yang digunakan adalah data sekunder yaitu data penelitian yang diperoleh secara tidak langsung melalui media perantara (diperoleh dan dicatat oleh orang lain). Sumber data untuk penelitian ini diperoleh dari situs Bursa Efek Indonesia melalui website www.idx.co.id dengan menganalisis rasio-rasio keuangan (current ratio, debt to assets ratio, total aset turnover, net profit margin) dari laporan keuangan tahunan diaudit pada perusahaan kelompok kategori manufaktur sektor industri dasar dan kimia dari mulai tahun 2012 sampai dengan tahun 2016. Metode penentuan sampel yang digunakan adalah teknik purposive sampling yaitu teknik yang digunakan dalam penentuan sampel yang dipilih berdasarkan kriteria tertentu dan berdasarkan pertimbangan tertentu yang disesuaikan dengan tujuan penelitian. Yaitu sebagai berikut:

1) Perusahaan manufaktur yang terdaftar di BEI yaitu Sektor Industri Dasar dan Kimia,

2) Perusahaan memiliki laporan keuangan yang telah diaudit dan telah dipublikasikan dari tahun 2012-2016.

3) Perusahaan tersebut memperoleh laba selama tahun yang diteliti yaitu dari tahun 20122016.

Berdasarkan kategori di atas, dari 64 perusahaan yang terdaftar di BEI hanya 21 perusahaan yang digunakan sebagai sampel yang memenuhi karakteristik tersebut dimana variabel independennya adalah Current Ratio (X1), Debt to Asset Ratio (X2), Total Asset Turnover (X3), Net Profit Margin (X4), dan variabel independennya Pertumbuhan Laba (Y).

Teknis analisis data yang digunakan adalah model analisis regresi berganda dengan bantuan software Eviews 9. Sebelum melakukan pengujian hipotesis, pengujian asumsi tidak dilakukan dalam penelitian ini karena metode yang digunakan adalah Generalised Least Squares (GLS) dimana data panel memiliki kelebihan yaitu tidak diperlukannya melakukan uji asumsi klasik. Untuk mendapatkan gambaran secara keseluruhan mengenai variabel-variabel yang digunakan, maka terlebih dahulu dilakukan analisis pada statistik deskriptif yang meliputi nilai rata-rata (mean), median, nilai maksimum dan minimum dan standar deviasi. Data yang digunakan adalah data panel balance. Data panel adalah data yang memiliki karakteristik cross section dan time series secara bersamaan. Sedangkan data panel balance adalah keadaan dimana unit cross-sectional memiliki jumlah observasi time series yang sama (Dr. Nurlelawati, 2017: 243). Adapun persamaan regresi linier berganda dirumuskan sebagai berikut:

$$
Y \text { it }=\alpha+\beta 1 X \text { it }+\beta 2 X \text { it }+\beta 3 X \text { it }+\beta 4 X \text { it }+\varepsilon \text { it }
$$

$$
\begin{array}{cl}
\text { Keterangan: } & \\
\text { Yit } & =\text { Pertumbuhan Laba (PL) } \\
& \text { manufaktur ke-i tahun ke-t } \\
\alpha & =\text { Konstanta } \\
\text { X1it } & =\text { Current Ratio (CR) } \\
& \text { manufaktur ke-i tahun ke-t } \\
\text { X2it } & =\text { Debt to Assets Ratio (DAR) } \\
& \text { manufaktur ke-i tahun ke-t } \\
\text { X3it } & =\text { Total Aset Turnover (TAT) } \\
& \text { manufaktur ke-i tahun ke-t } \\
\text { X4it } & =\text { Net Profit Margin (NPM) } \\
& \text { manufaktur ke-i tahun ke-t } \\
\beta 1 . . \beta 4 & =\text { Koefisien regresi } \\
\varepsilon & =\text { Tingkat kesalahan (standard } \\
& \text { error) }
\end{array}
$$

Dalam penelitian ini data time series diperoleh melalui periode waktu yaitu dari tahun 2012 sampai dengan 2016, sehingga data time series berjumlah 5. Adapun data cross section diambil dari 
data jumlah manufaktur yaitu 21 manufaktur sektor industri dasar dan kimia yang terdaftar di Bursa Efek Indonesia, sehingga jumlah observasinya sejumlah 105.

Interpretasi uji statistik yang digunakan tahap pertama adalah menguji koefisien determinan, merupakan uji yang dilakukan untuk mengetahui berapa besar hubungan dari beberapa variabel dalam pengertian yang lebih jelas. Koefisien determinasi akan menjelaskan seberapa besar perubahan atau variasi suatu variabel bisa dijelaskan oleh perubahan atau variasi pada variabel yang lain (Santosa \& Ashari, 2005:125). Koefisien determinasi dapat diketahui dengan melihat nilai R-squared (R2). Nilai koefisien determinasi akan cenderung semakin besar bila jumlah variabel bebas dan jumlah data yang diobservasi semakin banyak. Nilai koefisien ini antara 0 dan 1 , jika hasil lebih mendekati angka 0 berarti kemampuan variabel-variabel independen dalam menjelaskan variasi variabel amat terbatas. Tapi jika hasil mendekati angka 1 berarti variabel-variabel independen memberikan hampir semua informasi yang dibutuhkan untuk memprediksi variasi variabel dependen.

Tahap kedua adalah uji F(simultan), hasil uji F-statistik dapat disimpulkan dimana nilai Fstatistik yang signifikan mengindikasikan bahwa secara keseluruhan semua variabel independen mampu menjelaskan variabel dependennya. Hipotesis pada uji $\mathrm{F}$ adalah:

a) Ho: model regresi tidak signifikan

b) Ha: model regresi signifikan

Dasar pengambilan keputusan adalah:

1) Jika probabilitas $>\alpha$ maka $\mathrm{H}_{\mathrm{o}}$ diterima dan $\mathrm{H}_{\mathrm{a}}$ ditolak

2) Jika probabilitas $<\alpha$ maka $\mathrm{H}_{\mathrm{o}}$ ditolak dan $\mathrm{H}_{\mathrm{a}}$ diterima

Tahap ketiga uji t (parsial), digunakan untuk mengetahui pengaruh variabel bebas variabel bebas (CR, DAR, TAT, NPM) secara individual (parsial) terhadap variabel terikatnya (Pertumbuhan Laba), hipotesis pada uji $t$ adalah:

a) $\mathrm{H}_{\mathrm{o}}: \mathrm{b}=0$; atau model regresi tidak signifikan

b) $\mathrm{H}_{\mathrm{a}}: \mathrm{b}=0$; atau model regresi signifikan

Dasar pengambilan keputusan adalah:

1) Jika probabilitas $>\alpha$ maka $\mathrm{H}_{\mathrm{o}}$ diterima dan $\mathrm{H}_{\mathrm{a}}$ ditolak

2) Jika probabilitas $<\alpha$ maka $\mathrm{H}_{\mathrm{o}}$ ditolak dan $\mathrm{H}_{\mathrm{a}}$ diterima

Tahap keempat adalah menyusun model persamaan regresi berganda dan melihat bagaimana pengaruh variabel bebas (Current Ratio, Debt to Assets Ratio, Total Asset Turnover, Net Profit Margin) secara bersama-sama terhadap variabel terikatnya (Pertumbuhan Laba).

\section{PEMBAHASAN \\ Statistics Descriptive}

Tabel 1:

Output Hasil Deskriptif Statistik

\begin{tabular}{cccccc}
\hline & CR & $\mathbf{D A}$ & $\mathbf{T A}$ & $\mathbf{N P}$ & $\mathbf{P L}$ \\
& $\left(\mathbf{X}_{\mathbf{1}}\right)$ & $\mathbf{R}$ & $\mathbf{T}$ & $\mathbf{M}$ & $(\mathbf{Y})$ \\
Mean & 2.99 & 0.36 & 1.00 & 0.08 & 0.33 \\
& 621 & 565 & 407 & 358 & 260 \\
& 9 & 7 & 6 & 1 & 0 \\
Median & 2.15 & 0.33 & 0.91 & 0.06 & 0.01 \\
& 400 & 600 & 700 & 000 & 700 \\
Maximu & 0 & 0 & 0 & 0 & 0 \\
m & 13.8 & 0.83 & 2.10 & 0.27 & 13.3 \\
& 710 & 700 & 900 & 500 & 940 \\
& 0 & 0 & 0 & 0 & 0 \\
\hline
\end{tabular}




\begin{tabular}{cccccc}
\hline Minimu & 0.87 & 0.07 & 0.00 & 0.00 & - \\
$\mathrm{m}$ & 300 & 300 & 000 & 000 & 1.26 \\
& 0 & 0 & 0 & 0 & 000 \\
& & & & & 0 \\
St. Dev & 2.40 & 0.18 & 0.40 & 0.06 & 1.64 \\
& 364 & 552 & 585 & 891 & 500 \\
& 0 & 3 & 4 & 5 & 2 \\
Skewne & 2.16 & 0.63 & 0.59 & 1.16 & 5.76 \\
ss & 539 & 714 & 793 & 911 & 095 \\
& 3 & 1 & 0 & 8 & 7 \\
Kurtosis & 8.63 & 2.80 & 2.96 & 3.64 & 42.1 \\
& 871 & 673 & 742 & 371 & 700 \\
& 9 & 7 & 7 & 4 & 2 \\
Jarque- & 221. & 7.26 & 6.26 & 25.7 & 729 \\
Bera & 160 & 750 & 125 & 324 & 3.32 \\
& 0 & 1 & 3 & 9 & 2 \\
Probabil & 0.00 & 0.02 & 0.04 & 0.00 & 0.00 \\
ity & 000 & 641 & 369 & 000 & 000 \\
& 0 & 7 & 0 & 3 & 0 \\
Observa & 105 & 105 & 105 & 105 & 105 \\
tions & \multicolumn{7}{c}{} & & \\
\hline Sumber: data diolah dari & output reviews & 9.
\end{tabular}

Hasil analisis deskriptif menunjukkan bahwa current ratio memiliki nilai rata-rata (mean) positif sebesar 2.996219, debt to assets ratio sebesar 0.365657, total asset turnover sebesar 1.004076, net profit margin sebesar 0. 083581, dan pertumbuhan laba sebesar 0.332600 . nilai maximum tertinggi dimiliki oleh variabel current ratio yaitu sebesar 13.87100 dan nilai maximum terendah dimiliki oleh variabel net profit margin yaitu sebesar 0.275000 . current ratio memiliki nilai tertinggi standar deviasi yaitu sebesar 2.403640 dan net profit margin memiliki nilai standar deviasi terendah yaitu sebesar 0.068915 . dapat disimpulkan bahwa berdasarkan hasil analisis deskriptif tersebut menunjukkan secara umum semua variabel memiliki nilai statistik deskriptif positif.

\section{Uji Hipotesis}

Berdasarkan hasil pengujian tersebut di atas (tabel 1) dapat diinterpretasikan :

a. Uji Koefisien Determinan $\left(\mathrm{R}^{2}\right)$

Uji koefisien determinan digunakan untuk mengukur seberapa besar variable-variable bebas (CR, DAR, TAT, NPM) dapat menjelaskan variabel terikat (PL). Koefisien ini menunjukkan seberapa besar variasi total pada variabel terikat yang dapat dijelaskan oleh variabel bebasnya dalam model regresi tersebut. Dari hasil pengujian diperoleh R-Square $\left(\mathrm{R}^{2}\right)$ sebesar 0.121655, artinya variasi seluruh variabel bebas (Current Ratio, Debt to Assets Ratio, Total Asset Turnover, Net Profit Margin) dapat dipengaruhi variabel terikat (Pertumbuhan Laba) sebesar 12.1655\% (0.121655). sedangkan sisanya dipengaruhi oleh variabel lain diluar penelitian. Karena nilai $R$ Square cenderung mendekati nilai 0 maka dapat disimpulkan kemampuan variabel-variabel independen dalam menjelaskan variasi variabel amat terbatas.

b. Analisis Variansi / Uji F-Statistik

Uji F-statistik bertujuan untuk menguji pengaruh variabel bebas (Current Ratio, Debt to Assets Ratio, Total Asset Turnover, Net Profit Margin) secara bersama-sama atau keseluruhan (simultan) terhadap variabel tak bebas (Pertumbuhan Laba).

Berdasarkan tabel 4.2, nilai probabilitas (F-Statistik) sebesar $0.010801<0.05$ sehingga dapat disimpulkan bahwa Ho ditolak dan Ha diterima, artinya variabel bebas 
(Current Ratio, Debt to Assets Ratio, Total Asset Turnover, Net Profit Margin) berpengaruh secara bersama-sama terhadap variabel bebas (Pertumbuhan Laba).

Tabel 2 :

Rangkuman Uji t

\begin{tabular}{|c|c|c|c|l|}
\hline $\begin{array}{c}\text { Varia } \\
\text { bel }\end{array}$ & N & $\begin{array}{c}\text { Sig. } \\
\text { hitung }\end{array}$ & $\boldsymbol{\alpha}$ & $\begin{array}{l}\text { Keterang } \\
\text { an }\end{array}$ \\
\hline $\mathrm{X} 1$ & 105 & $\begin{array}{c}0.234 \\
7\end{array}$ & 0.05 & $\begin{array}{l}\text { Ha } \\
\text { ditolak/Ti } \\
\text { dak } \\
\text { signifikan }\end{array}$ \\
\hline $\mathrm{X} 2$ & 105 & $\begin{array}{c}0.033 \\
2\end{array}$ & 0.05 & $\begin{array}{l}\text { Ha } \\
\text { diterima/s } \\
\text { ignifikan }\end{array}$ \\
\hline $\mathrm{X} 3$ & 105 & $\begin{array}{c}0.011 \\
0\end{array}$ & 0.05 & $\begin{array}{l}\text { Ha } \\
\text { diterima/s } \\
\text { ignifikan }\end{array}$ \\
\hline $\mathrm{X} 4$ & 105 & 0.009 & 0.05 & $\begin{array}{l}\text { Ha } \\
\text { diterima/s } \\
\text { ignifikan }\end{array}$ \\
\hline
\end{tabular}

Dependent Variable: PL

Method: Panel EGLS (Cross-section weights)

Date: 01/10/18 Time: 18:19

Sample: 20122016

Periods included: 5

Cross-sections included: 21

Total panel (balanced) observations: 105

Linear estimation after one-step weighting matrix

\begin{tabular}{|c|c|c|c|c|}
\hline Variable & Coefficient & Std. Error & t-Statistic & Prob. \\
\hline $\mathrm{C}$ & -0.850080 & 0.297081 & -2.861440 & 0.0051 \\
\hline CR & 0.037992 & 0.031779 & 1.195528 & 0.2347 \\
\hline DAR & 1.013123 & 0.469120 & 2.159627 & 0.0332 \\
\hline TAT & 0.283904 & 0.109525 & 2.592124 & 0.0110 \\
\hline NPM & 2.204407 & 0.831362 & 2.651561 & 0.0093 \\
\hline \multicolumn{5}{|c|}{ Weighted Statistics } \\
\hline R-squared & 0.121655 & \multirow{5}{*}{\multicolumn{2}{|c|}{$\begin{array}{l}\text { Mean dependent var } \\
\text { S.D. dependent var } \\
\text { Sum squared resid } \\
\text { Durbin-Watson stat }\end{array}$}} & 0.368220 \\
\hline Adjusted R-squared & 0.086521 & & & 1.425863 \\
\hline S.E. of regression & 1.370062 & & & 187.7069 \\
\hline F-statistic & 3.462612 & & & 2.037095 \\
\hline \multirow[t]{2}{*}{ Prob(F-statistic) } & 0.010801 & & & \\
\hline & \multicolumn{3}{|c|}{ Unweighted Statistics } & \\
\hline R-squared & -0.023671 & Mean dependent var & & 0.332600 \\
\hline Sum squared resid & 288.0889 & Durbin-Watson stat & & 1.751596 \\
\hline
\end{tabular}

Sumber : Pengolahan Data Eviews 9 
1) Berdasarkan tabel 2 di atas, oleh karena nilai probabilitas $0.2347>0.05$ maka variabel current ratio (X1) tidak terdapat pengaruh signifikan terhadap pertumbuhan laba (Y), hasil ini selaras dengan penelitian yang dilakukan oleh Khalidazia Ibnu Khaldun (2014) yang menyatakan bahwa current ratio memiliki nilai probabilitas 0,6427 yang berarti tidak memiliki pengaruh yang signifikan terhadap pertumbuhan laba.

2) Variabel debt to assets ratio (X2) memiliki nilai probabilitas $0.0332<0.05$, dapat disimpulkan bahwa variabel debt to assets ratio (X2) berpengaruh positif signifikan terhadap pertumbuhan laba $(\mathrm{Y})$, hasil penelitian ini tidak selaras dengan hasil penelitian oleh Ima Andriyani (2015) yang menyatakan bahwa debt to asset ratio memiliki nilai probabilitas sebesar 0,857 yang berarti tidak signifikan.

3) Variabel total asset turnover ratio (X3) memiliki nilai probabilitas $0.0110<0.05$ sehingga variabel total asset turnover ratio $(X 3)$ berpengaruh positif signifikan terhadap pertumbuhan laba $(\mathrm{Y})$, hasil ini selaras dengan hasil penelitian Purwanto (2016) yang menyatakan bahwa total asset turnover memiliki nilai probabilitas sebesar 0,007 yang berarti memiliki pengaruh signifikan tetapi tidak selaras dengan penelitian yang dilakukan oleh Ima Andriyani (2015) yang menyatakan bahwa total asset turnover memiliki nilai probabilitas sebesar 0,729 yang berarti tidak berpengaruh signifikan terhadap pertumbuhan laba.

4) Variabel net profit margin (X4) memiliki nilai probabilitas $0.0093<0.05$, dan variabel net profit margin $(\mathrm{X} 4)$ berpengaruh positif signifikan terhadap pertumbuhan laba (Y), hasil ini selaras dengan hasil penelitian yang dilakukan oleh Nyoman Kusuma Andriyana (2012) yang menyatakan bahwa net profit margin memiliki nilai probabilitas 0,000 yang berarti berpengaruh signifikan terhadap pertumbuhan laba.

c. Analisis Variansi / Uji F-Statistik

Uji F-statistik bertujuan untuk menguji pengaruh variabel bebas (Current Ratio, Debt to Assets Ratio, Total Asset Turnover, Net Profit Margin) secara bersama-sama atau keseluruhan (simultan) terhadap variabel tak bebas (Pertumbuhan Laba).

Berdasarkan tabel 4.2, nilai probabilitas (F-Statistik) sebesar $0.010801<0.05$ sehingga dapat disimpulkan bahwa Ho ditolak dan Ha diterima, artinya variabel bebas (Current Ratio, Debt to Assets Ratio, Total Asset Turnover, Net Profit Margin) berpengaruh secara bersama-sama terhadap variabel bebas (Pertumbuhan Laba).

d. Analisis penyusunan model regresi berganda

Berdasarkan tabel 4.2, diperoleh pengaruh Current Ratio, Debt to Assets Ratio, Total Asset Turnover, dan Net Profit Margin terhadap Pertumbuhan Laba dapat digambarkan dengan persamaan:

$Y=-0,850+0,037 X 1+1,013 X 2+0,284 X 3+2,204 X 4$

Interpretasinya adalah:

1) $\alpha=-0,850$ artinya bahwa apabila current ratio, debt to assets ratio, total asset turnover, dan net profit margin konstan, maka pertumbuhan laba sebesar -0,850.

2) Nilai koefisien regresi current ratio (X1) sebesar 0,037 artinya jika current ratio naik 1 rupiah maka pertumbuhan laba akan meningkat sebesar 0,037 atau jika current ratio naik 1.000 rupiah, maka pertumbuhan laba akan naik sebesar Rp 37 begitu juga sebaliknya, jika current ratio turun 1.000 rupiah maka pertumbuhan laba akan turun $\mathrm{Rp} 37$. Karena hasil uji hipotesis variabel current ratio menerima $\mathrm{HO}$ atau tidak signifikan maka current ratio tidak dapat digunakan sebagai alat untuk menjelaskan dan mengambil keputusan mengenai pengaruh current ratio terhadap pertumbuhan laba. 
3) Nilai koefisien regresi debt to assets ratio (X2) sebesar 1,013 artinya jika debt to assets ratio naik 1 rupiah maka pertumbuhan laba akan meningkat sebesar 1,013 atau jika debt to assets ratio naik 1.000 rupiah, maka pertumbuhan laba akan naik sebesar Rp 1.013 begitu juga sebaliknya, jika debt to assets ratio turun 1.000 rupiah maka pertumbuhan laba akan turun $\mathrm{Rp} 1.013$.

4) Nilai koefisien regresi total asset turnover ( $X 3$ ) sebesar 0,284 artinya jika total asset turnover naik 1 rupiah maka pertumbuhan laba akan naik sebesar 0,284 atau jika harga naik 1.000 rupiah, maka pertumbuhan laba akan naik sebesar Rp 284. begitu juga sebaliknya, jika total asset turnover turun 1.000 rupiah maka pertumbuhan laba akan turun Rp Rp 284.

5) Nilai koefisien regresi net profit margin (X4) sebesar 2,204 artinya jika net profit margin naik 1 rupiah maka pertumbuhan laba akan naik sebesar 2,204 atau jika harga naik 1.000 rupiah, maka pertumbuhan laba akan naik sebesar Rp 2.204. begitu juga sebaliknya, jika net profit margin turun 1.000 rupiah maka pertumbuhan laba akan turun Rp Rp 2.204.

\section{PENUTUP}

Kesimpulan

Current ratio menunjukkan tidak terdapat pengaruh signifikan terhadap pertumbuhan laba pada perusahaan manufaktur sektor industri dasar dan kimia yang terdaftar di Bursa Efek Indonesia ,dimana nilai profitabilitasnya $>0,05$,

Debt to asset ratio menunjukkan adanya pengaruh signifikan terhadap pertumbuhan laba pada perusahaan manufaktur sektor industri dasar dan kimia yang terdaftar di Bursa Efek Indonesia, dimana memiliki nilai probabilitas $<0,05$.

Total asset turnover menunjukkan adanya pengaruh signifikan terhadap pertumbuhan laba pada perusahaan manufaktur sektor industri dasar dan kimia yang terdaftar di Bursa Efek Indonesia, dimana memiliki nilai probabilitas $<0,05$.

Net profit margin menunjukkan adanya pengaruh signifikan terhadap pertumbuhan laba pada perusahaan manufaktur sektor industri dasar dan kimia yang terdaftar di Bursa Efek Indonesia, dimana memiliki nilai probabilitas $<0,05$.

Secara simultan, current ratio, debt to asset ratio, total asset turnover dan net profit margin memiliki pengaruh signifikan terhadap pertumbuhan laba.

Saran

Sebaiknya perusahana mengubah aktiva lancar tertentu menjadi kas untuk membayar utang lancarnya yang tidak lebih dari satu tahun agar tingkat likuiditas meningkat sehingga aktiva lancar dapat menjamin hutang lancar yang ada.

Assets yang dimiliki dapat digunakan perusahaan untuk memperoleh pinjaman dari para investor sehingga assets dapat memberikan konstribusi yang tinggi pada peningkatan laba

Jika ingin memiliki pertumbuhan laba yang terus meningkat dalam menigkatkan kinerja perusahaan, maka perusahaan dapat memanfaatkan aktiva yang dimiliki dengan meningkatkan perputaran total asset.

Pada kenyataannya, peningkatan penjualan tidak selalu diikuti oleh adanya peningkatan laba, oleh karena itu selain terus meningkatkan pendapatan, perusahaan juga harus terus mampu menekan biaya operasional agar tidak terjadi peningkatan dan terus memperbaiki pengelolaan operasional. 


\section{REFERENSI}

Amin, Sulfida Syahliza. 2010. Pengaruh Rasio Keuangan Terhadap Pertumbuhan Laba Pada Perusahaan Barang konsumsi Yang Terdaftar di Bursa Efek Indonesia. Medan : Universitas Sumatera Utara. Diunduh melalui http://repository.usu.ac.id/handle/123456789/18037

Andriyani, I. 2015. Pengaruh Rasio keuangan Terhadap Pertumbuhan Laba Pada Perusahaan Pertambangan yang Terdaftar di Bursa Efek Indonesia. Jurnal Manajemen dan Bisnis Sriwijaya Vol.13 No.3 September.

Belkaoui, Ahmed Riahi. 2007. Accounting Theory. 5th Edition. Buku 2. Edisi Terjemahan. Jakarta ; Salemba Empat

Copelan, Tomas dan Wetson J. Fred. 1995. Manajemen sKeuangan, Edisi Delapan, Jilid I, Alihbahasa : Jaka Wasana \& Kirbrandoko. Jakarta: Gelora Aksara Pratama.

Fahmi, Irham. 2013. Analisis laporan keuangan. Bandung: Alfabeta

Ghozali, Imam. A. C. 2007. Teori Akuntansi. Semarang: Badan Penerbit Universitas Dipenogoro.

Gunawan, Ade dan Sri Safitri Wahyuni. 2013. Pengaruh Rasio Keuangan Terhadap Petumbuhan Laba pada Perusahaan Perdagangan Di Indonesia. Jurnal Manajemen \& Bisnis. VOL 13 NO. 01 APRIL 2013. ISSN 1693-7619.

Hamidu, Novian P. 2013. Pengaruh Kinerja Keuangan Terhadap Pertumbuhan Laba Pada Perbankan di BEI. Jurnal EMBA. Vol.1 No.3 Juni 2013, Hal. 711-721.

Harahap, Sofyan Syafari. 2015. Analisa Kritis Atas Laporan Keuangan. Cetakan 11. Jakarta: PT. Rajagrafindo Persada.

Harahap, Sofyan Syafari.2011. Analisa Kritis Atas Laporan Keuangan. Cetakan 11. Jakarta: PT. Rajagrafindo Persada.

Harahap, Sofyan Syafari. 2010. Analisis Kritis atas laporan Keuangan . Jakarta: Raja Grafindo Persada.

Hartini, Windi. 2012. Pengaruh Financial Ratio Terhadap Pertumbuhan Laba dengan Pengungkapan Corporate Social Responsibility sebagai Variabel. Management Analysis Journal. Agustus 2012.

Hartono, Jogiyanto. 2003. Teori Portofolio dan Analisis Investasi, Edisi Ketiga. Yogyakarta: BPFE UGM.

Hendriksen, Eldon S. 1996. Teori Akuntansi. Edisi Empat. Dialihbahasakan oleh Nugroho Widjayanto. Jakarta : Erlangga

Horne, James C dan John M Wachowicz, Jr. 2012. Prinsip-Prinsip Manajemen Keuangan (Edisi 13). Jakarta : Salemba Empat

Ikatan Akuntan Indonesia. 2009. Standar Akuntansi Keuangan. PSAK No.1 Penyajian Laporan Keuangan. Jakarta: Salemba Empat.

Ikatan Akuntan Indonesia. 2007. Standar Akuntansi Keuangan. Jakarta : Salemba Empat

Kasmir. 2016. Analisa Laporan Keuangan. Cetakan Kesembilan. Jakarta: PT. Rajagrafindo Persada.

Khaldun, K. I. 2014. The Influence of Profitability Fand Liquidity Ratio on The Growth of Profit of Manufacturing Companies. International Journal of Economics, Commerce and Management, Vol. II, Issue 12, Dec.

Mahaputra, I Nyoman Kusuma Adnyana. 2012. Pengaruh Rasio-rasio Keuangan terhadap Pertumbuhan Laba pada Perusahaa Manufaktur Terdaftar di BEI. Jurnal Akuntansi dan Bisnis, Vol 7 No.2 Juli.

Meyti. 2005. Rasio Keuangan yang Paling Baik untuk Memprediksi Pertumbuhan Laba pada Perusahaan Manufaktur yang Terdaftar di Bursa Efek Jakarta. Jurnal Ekonomi dan Bisnis, Vol XI No.2 September.

Munir, R. 2017. dari forum teropong (http://forum.teropong.id/2017/09/30/pengertian-laba karakteristik-unsur-unsur-jeni-jenis-dan-faktor-yang mempengaruhi-laba/). $\quad 30$ September 2017.

Nafarin, M. 2007. Penganggaran Perusahaan. Edisi Ketiga. Jakarta : Salemba Empat. 
Nurlelawati, Lela. 2017. Metodologi Penelitian Bisnis Terapan Aplikasi SPSS, Eviews, Smart $P L S$, dan AMOS. Bandung : CV. Mujahid Press.

Purwanto, C. R. 2016. Analysis of Financial Ratio towards Earning Growth in Mining Companies. Universal Journal of Industrial and Business Management 4(3), 81-87.

Rahardjo, Budi. 2007. Keuangan dan Akuntansi, Edisi Pertama, Cetakan Pertama. Yogyakarta: Graha Ilmu.

Riyanto, Bambang. 2011. Dasar-dasar Pembelanjaan Perusahaan. Edisi Keempat. Cetakan Ketujuh. Yogyakarta: BPFE UGM.

Santosa, Budi Perbayu dan Ashari. 2005. Analisis Statistik Dengan Microsoft Excel dan SPSS. Yogyakarta: Andi Offset.

Soemarso. 2010. Akuntansi Suatu Pengantar, Edisi Lima buku Dua. Jakarta: Salemba Empat.

Stice, Earl K, James D Stice dan Fred Skousen. 2009. Akuntansi Keuangan Menengah. Edisi 16, Buku 2, Edisi Bahasa Indonesia, Terjemahan Ali Akbar. Jakarta : Salemba Empat

Sutrisno. 2012. Manajemen Keuangan Teori Konsep dan Aplikasi. Yogyakarta: Ekonisia.

Sutrisno. 2009. Manajemen Keuangan Teori Konsep dan Aplikasi. Edisi Pertama. Cetakan Ketujuh. Yogyakarta: Ekonisia

Suwardjono. 2008. Manajemen Keuangan. Edisi Ketiga. Jakarta: Mitra Wacana Media.

Syamsuddin, Lukman. 2009. Manajemen Keuangan Perusahaan. Jakarta: PT. Raja Grafindo Persada.

Tim Penyusun. 2011. Unit Pengembangan Fakultas Ekonomi, Modul eviews 6. Universitas Dipenogoro. (p. 14). Semarang.

http://www.idx.co.id 